\title{
Program för miljö
}

Sveriges ordförandeskap 2018

\section{(1I) Nordiska} ministerrådet 


\section{Program för miljö}

Sveriges ordförandeskap 2018 i Nordiska ministerrådet

ANP 2017:793

ISBN 978-92-893-5310-6 (PRINT)

ISBN 978-92-893-5311-3 (PDF)

ISBN 978-92-893-5312-0 (EPUB)

http://dx.doi.org/10.6027/ANP2017-793

(C) Nordiska ministerrådet 2017

Layout: Louise Jeppesen

Omslagsfoto: unsplash.com

\section{Det nordiska samarbetet}

Det nordiska samarbetet är ett av världens mest omfattande regionala samarbeten. Det omfattar Danmark, Finland, Island, Norge och Sverige samt Färöarna, Grönland och Åland.

Det nordiska samarbetet är politiskt, ekonomiskt och kulturellt förankrat och en viktig del av europeiskt och internationellt samarbete. Den nordiska gemenskapen arbetar för ett starkt Norden i ett starkt Europa.

Det nordiska samarbetet vill styrka nordiska och regionala intressen och värderingar i en global omvärld. Gemensamma värderingar länderna emellan bidrar till att stärka Nordens ställning som en av världens mest innovativa och konkurrenskraftiga regioner.

\section{Nordiska ministerrådet \\ Nordens Hus \\ Ved Stranden 18 \\ 1061 København K \\ www.norden.org}

Ladda ner nordiska publikationer: www.norden.org/nordpub 



\section{Miljöministerns inledande ord}

Miljö- och klimatsamarbetet i Nordiska ministerrådet är brett och inkluderar de flesta områden som påverkar vår miljö, våra ekosystem och vårt klimat. De erfarenheter vi har av det nordiska samarbetet ger oss en unik kunskap om att välfärdsutveckling, ekonomisk utveckling och en god miljö går att förena. Sverige tar inför sitt ordförandeskap 2018 avstamp i detta och inriktar sig på den omställning våra samhällen måste gå igenom för att uppfylla de internationella överenskommelser Norden förbundit sig att genomföra - Parisavtalet och FN:s mål för en hållbar utveckling, Agenda 2030. Sverige fokuserar arbetet på att kommunicera och utveckla de möjligheter som finns i den omfattande kunskap som generellt skapas inom ramen för den nordiska miljö- och klimatsektorn och vi väljer särskilt att lyfta fram en del av de projekt som sektorns arbetsgrupper bidrar med.

\section{Karolina Skog}

Sveriges miljöminister

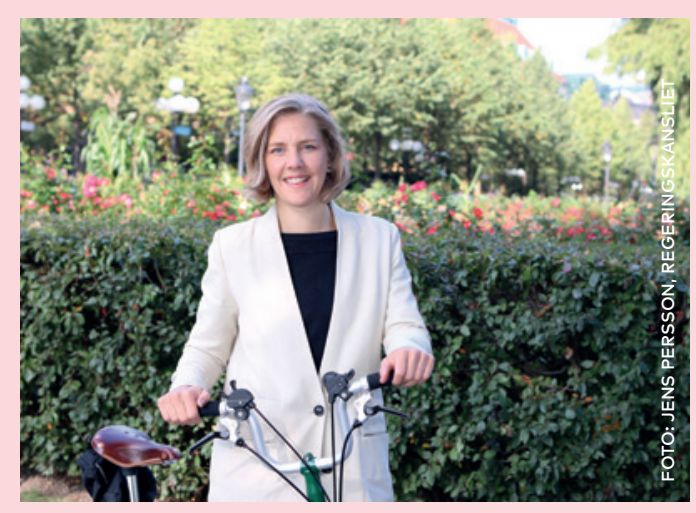




\section{Nordens klimat och miljö}

\section{LEVANDE STÄDER}

Levande städer sätter människan i centrum. Det kan handla om vikten av att enkelt kunna ta sig fram i vardagen - med kollektivtrafik, gångtrafik eller cykeltrafik. Den sociala dimensionen och jämställdhetsperspektivet är viktiga att lyfta fram och statistiken visar till exempel att fler kvinnor än män åker kollektivtrafik. Det svenska ordförandeskapsprojektet om hållbara nordiska städer med fokus på klimatsmart mobilitet lägger tonvikt på omställningen till fossilfria och hållbara transporter i städer. Vi vill visa att de nordiska länderna ligger långt framme i ett internationellt perspektiv och att det finns mycket kunskap som vi kan dela med oss av.

\section{Aktiviteter}

- Ett av Sveriges övergripande ordförandeskapsprojekt har inriktning på "Hållbara nordiska städer med fokus på klimatsmart mobilitet". Projektet inleds under 2018 och sträcker sig till 2020. Det syftar till att bidra till en hållbar stadsutveckling genom att stödja omställningen till fossilfria och hållbara person- och godstransporter i nordiska städer och stadsregioner.

Ansvarig: Miljö- och energidepartementet tillsammans med Näringsdepartementet.

Tidpunkt: 2018-2020

Målgrupp: Nordiska tjänstemän på nationell, regional och lokal nivå.

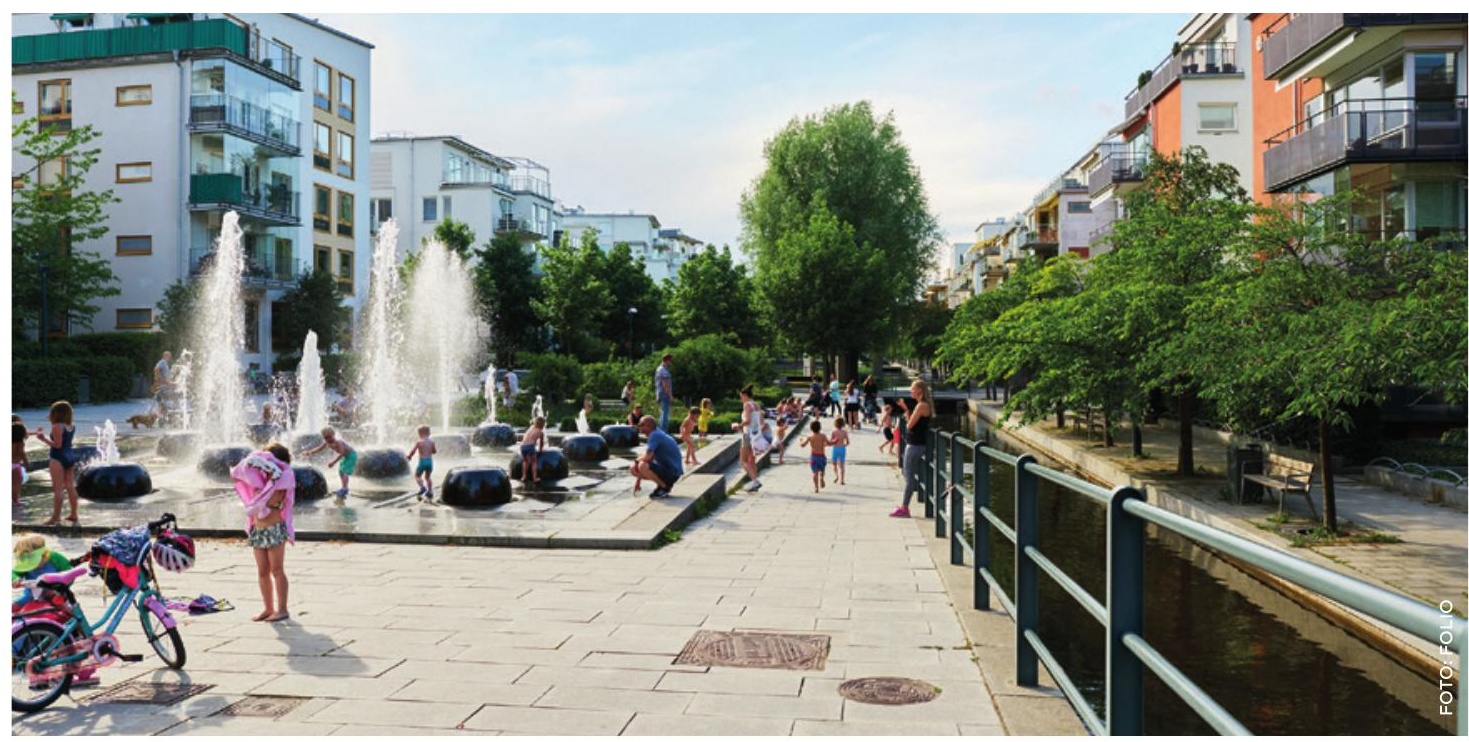


- Under höstens miljö- och klimatministermöte diskuteras temat "Hållbara städer - hur utvecklar vi gröna, jämställda och levande städer?". En extern inspirationsföreläsare bjuds in. Fokus läggs på att dela erfarenheter av att utveckla gröna strukturer i städer. Diskussionens slutsatser kommuniceras och sprids i Norden till relevanta politiska nivåer.

Ansvarig: Miljö- och energidepartementet och det nordiska Terrestra ekosystemgruppen (TEG).

Tidpunkt: 31 oktober 2018 Målgrupp: Ministrarna och i nästa fas berörda myndigheter.

\section{KLIMAT}

Klimatförändringarna är en av mänsklighetens största utmaningar. Parisavtalet har trätt i kraft och därmed har den globala ambitionsnivån höjts avsevärt. Ett omfattande arbete med att genomföra avtalet har inletts. Alla länder måste höja sina klimatambitioner för att Parisavtalets mål - att hålla den globala uppvärmningen långt under två grader Celsius och helst under 1,5 grader jämfört med förindustriell nivå - ska nås. De nordiska länderna delar behovet att ställa om våra samhällen till att bli grönare och mer hållbara. Utmaningen att minska utsläppen är stor, inte minst i transportsektorn. Samtidigt har de nordiska länderna

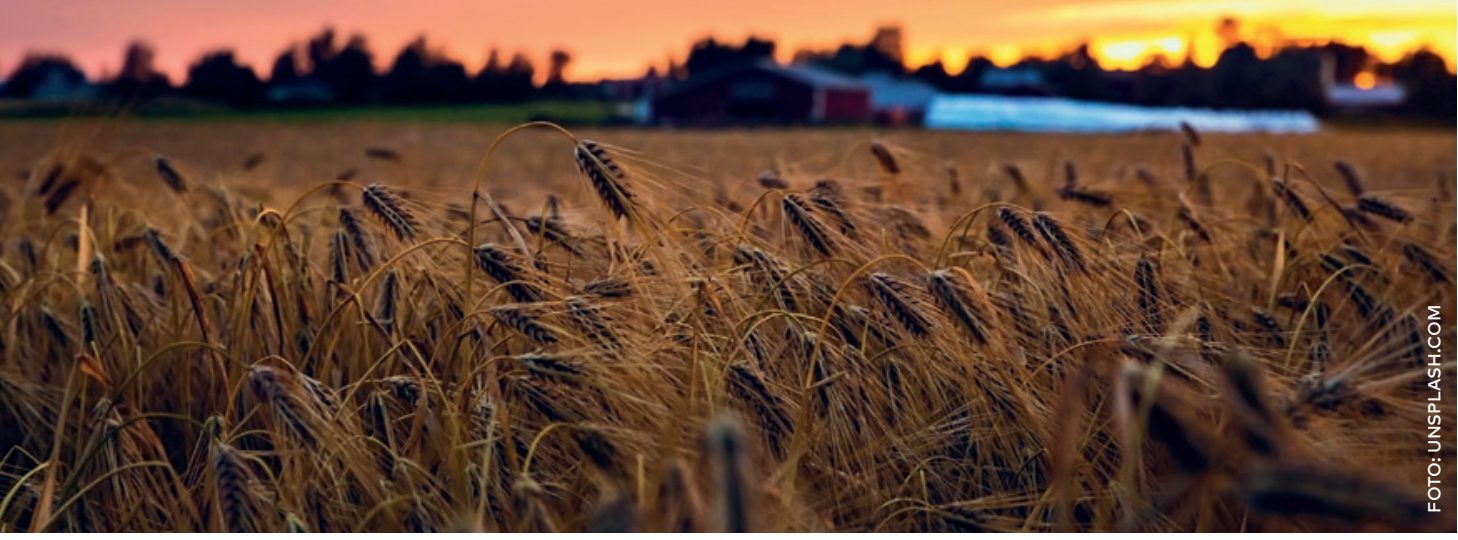


goda möjligheter att ta en ledande roll i genomförandet av Parisavtalet och även av FN:s nya globala mål för en hållbar utveckling, Agenda 2030. Genom ett grönt samhällsbygge kan en långsiktigt hållbar ekonomi, en god miljö och ett ökat välstånd skapas i hela Norden. Det nordiska samarbetet på klimatområdet har bidragit till en ökad kunskapsnivå och främjat erfarenhetsutbyte mellan de nordiska länderna. Tillsammans vill vi också dela med oss av de lärdomar vi dragit till länder även utanför Norden.

Det nordiska samarbetet i klimatförhandlingarna är fortsatt viktigt. Vid FN:s klimatmöte i slutet av 2018 (COP24) kommer den så kallade Talanoa-dialogen (tidigare stödjande dialogen) att genomföras. Arbetet med att genomföra Parisavtalets regelbok är prioriterat under året och under 2018 presenterar också FN:s klimatpanel (IPCC) en rapport som fokuserar på möjligheterna att hålla den globala temperaturökningen under 1,5 grader.

\section{Aktiviteter}

- Sverige väljer att följa upp på Norges tema om arbetet med en grön omställning och arrangerar ett möte mellan företrädare för det nordiska näringslivet och de nordiska miljö- och klimatministrarna. Det finns många nordiska exempel som visar att det är möjligt att förena klimatomställning med god ekonomisk utveckling. Fokus läggs därför på att diskutera hur näringsliv och stat kan samarbeta och lära av varandra för att på så sätt stärka potentialen för grön omställning. Vi följer också upp Oslodeklarationen om hur de nordiska länderna kan gå före i frågan om höjda ambitionsnivåer och visa på ledarskap såväl nationellt som internationellt.

Ansvarig: Miljö- och energidepartementet.

Tidpunkt: 13 april 2018

Målgrupp: Ministrar och företagsledare.

- Under Nordiska rådets session hösten 2018 ordnas en diskussion om IPCC:s specialrapport om den globala uppvärmningen till 1,5 grader och vilka effekter den kan medföra.

Ansvarig: Miljö- och energidepartementet med stöd av Nordiska arbetsgruppen för globala klimatförhandlingar (NOAK). Tidpunkt: 31 oktober 2018 Målgrupp: Nordiska ministrar och andra politiker. 


\section{KLIMATANPASSNING}

Nordiska konferenser om klimatanpassning har arrangerats under ett flertal år. De nordiska länderna delar många av de utmaningar som ett förändrat klimat innebär, och vi kan arbeta tillsammans för att bygga resilienta och hållbara samhällen. Syftet med konferenserna är att belysa, diskutera och bli inspirerade av varandras lösningar på klimatanpassningsområdet. Konferenserna bidrar också till ökad kunskap om klimatförändringar, samt till insikter om hur lösningar för klimatanpassning och minskade utsläpp av växthusgaser kan integreras.

\section{Aktivitet}

- Den femte Nordiska klimatanpassningskonferensen arrangeras i Norrköping av SMHI, Norrköpings kommun och Linköpings universitet. Konferensen arrangeras vartannat år, och tidigare konferenser har hållits i Bergen, Köpenhamn, Helsingfors och Stockholm.

Ansvarig: SMHI (Sveriges meteorologiska och hydrologiska institut).

Tidpunkt: 23-25 oktober 2018 Målgrupp: Beslutsfattare, sakkunniga på alla nivåer, forskare, representanter från näringslivet, nationella myndigheter och NGOs.

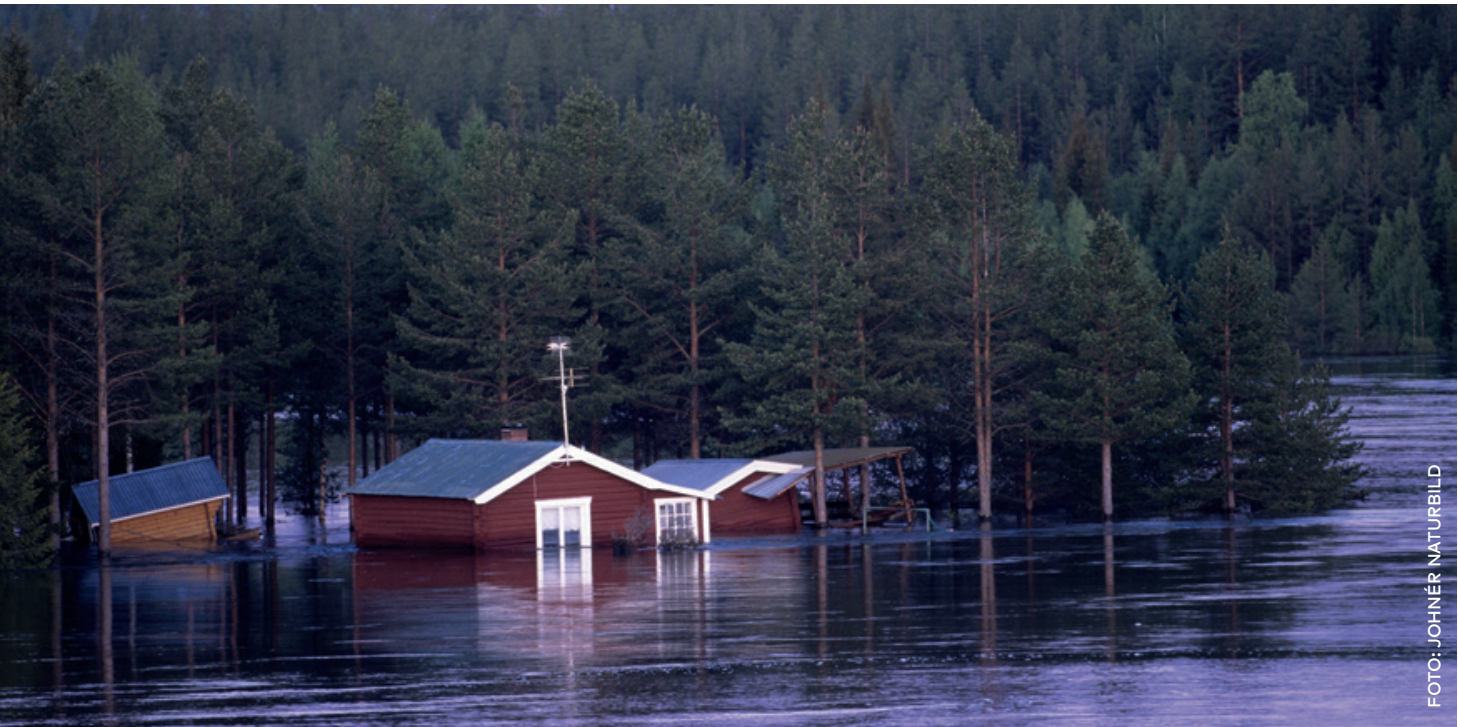




\section{LUFT}

Luftvårdspolitiken står nu inför en ny era i det internationella luftvårdsarbetet. Inom EU har en ny luftvårdspolitik sjösatts i och med att nya direktiv har beslutats. Inom FN:s luftvårdskonvention presenterades i maj 2016 den vetenskapliga rapporten "Towards Cleaner Air", som pekar på dagens utmaningar och möjligheter inom det internationella luftvårdsarbetet. Baserat på rapporten arbetar nu konventionen vidare med framtidens policyinstrument och nya protokoll. FN:s Agenda 2030 ger dessutom möjligheter att arbeta mer integrerat mellan luft och andra policyområden.

\section{Aktivitet}

- En workshop arrangeras, som blir den sjätte i en serie strategiska luftvårdsmöten, så kallade Saltsjöbadsmöten. Sverige har tidigare stått värd för dessa möten vid tillfällen då det internationella luftvårdsarbetet stått inför nya utmaningar. Behovet av ett nära utbyte mellan forskare och beslutsfattare för att staka ut den framtida riktningen är nu betydande. Det senaste mötet i Saltsjöbadsserien anordnades 2013 med cirka 150 forskare och beslutsfattare från 30 länder från samtliga kontinenter.

Ansvarig: Den nordiska Klimat- och luftgruppen (KOL).

Tidpunkt: 19-21 mars 2018

Målgrupp: Beslutsfattare och forskare men även representanter för industrin och NGOs.

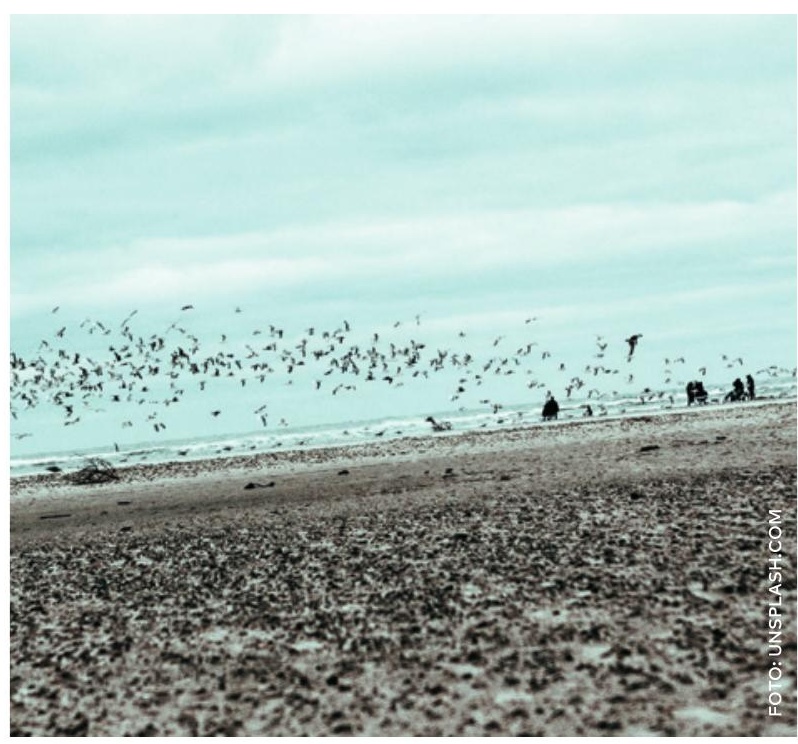




\section{EKONOMISKA STYRMEDEL FÖR GRÖN OMSTÄLLNING}

Långsiktiga och förutsägbara regler som att förorenaren ska betala och att pris sätts på utsläpp - är några av de faktorer som ligger bakom den gröna omställningen i de nordiska länderna. En kostnadseffektiv miljöpolitik innebär att fler miljöåtgärder kan genomföras och att rätt incitament till teknikutveckling skapas. Ekonomiska styrmedel har använts i de nordiska ländernas miljöoch klimatpolitik sedan tidigt 1990-tal och har i hög grad bidragit till omställningen till en mer hållbar utveckling $i$ de nordiska länderna. Den kunskap och erfarenhet som de nordiska länderna har byggt upp kan spela en viktig roll när exempelvis utvecklingsländer nu ska genomgå liknande omställningar.

\section{Aktivitet}

- Under 2018 publiceras en fjärde upplaga av rapporten "Ekonomiska styrmedel i miljöpolitiken". Den kartlägger användningen av ekonomiska styrmedel i de nordiska länderna under de senaste fyra åren. Parallellt med framtagandet av denna rapport görs en analys av vad som skett över tiden med de totalt fyra rapporterna, det vill säga under perioden 2011-2017.

Ansvarig: Den nordiska Miljö- och ekonomigruppen (MEG).

Tidpunkt: 2018

Målgrupp: Politiker, tjänstemän och NGOs.

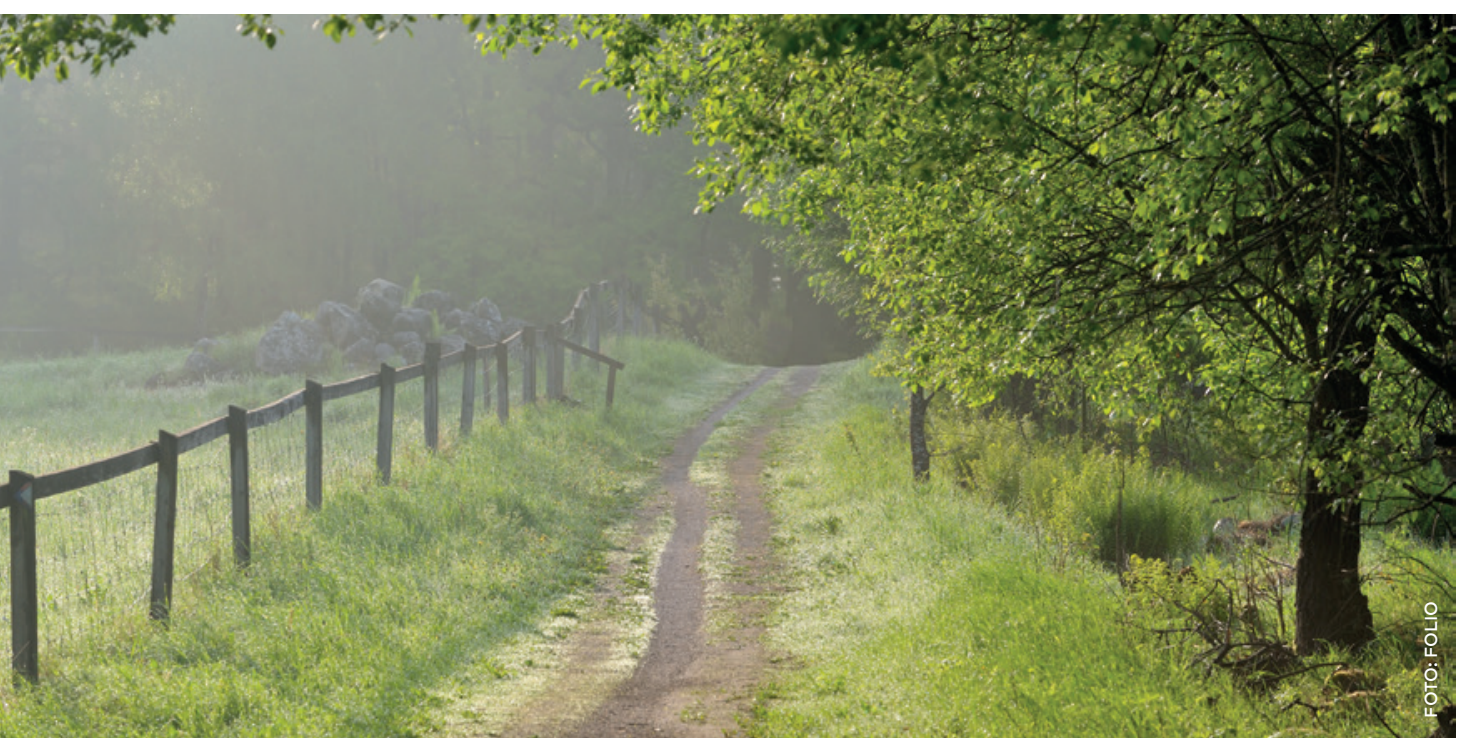




\section{HAV}

Utvecklingen i våra världshav går åt fel håll. Föroreningar, skräp, havsförsurning, uppvärmning och utarmning av biologisk mångfald leder till en allt sämre havsmiljö och allt sämre förutsättningar för livsmedelssäkerhet och fattigdomsbekämpning i världen. Samarbete kring havsmiljöfrågor har prioriterats av flera tidigare ordförandeskap och kommer att fortsatt vara prioriterat under det svenska ordförandeskapet.

Konkreta åtgärder för att minska mängden marint skräp och mikroplaster står i centrum för arbetet 2018. Vi bör arbeta för att fler områden skyddas, men också samtidigt beakta andra typer av möjliga förvaltningsinstrument för att värna våra hav. Behovet av mer kunskap om effekterna av uppvärmningen av haven är stort och bör liksom havsförsurningen stå i fokus under de kommande åren.

Sverige stod i juni 2017, tillsammans med Fiji, värd för FN:s havskonferens om genomförandet av det globala hållbarhetsmålet för hav (SDG14). Resultatet av konferensen följs upp ur ett nordiskt perspektiv under Sveriges ordförandeskap.

\section{Aktivitet}

- En nordisk ministerdiskussion om resultatet av FN:s havskonferens arrangeras. Fokus ligger på hur arbetet med genomförande av SDG14 kan stärkas i det nordiska samarbetet - såväl regionalt som globalt.

Ansvarig: Miljö- och energidepartementet tillsammans med den nordiska Havgruppen (HAV).

Tidpunkt: 13 april

Målgrupp: Ministrar.

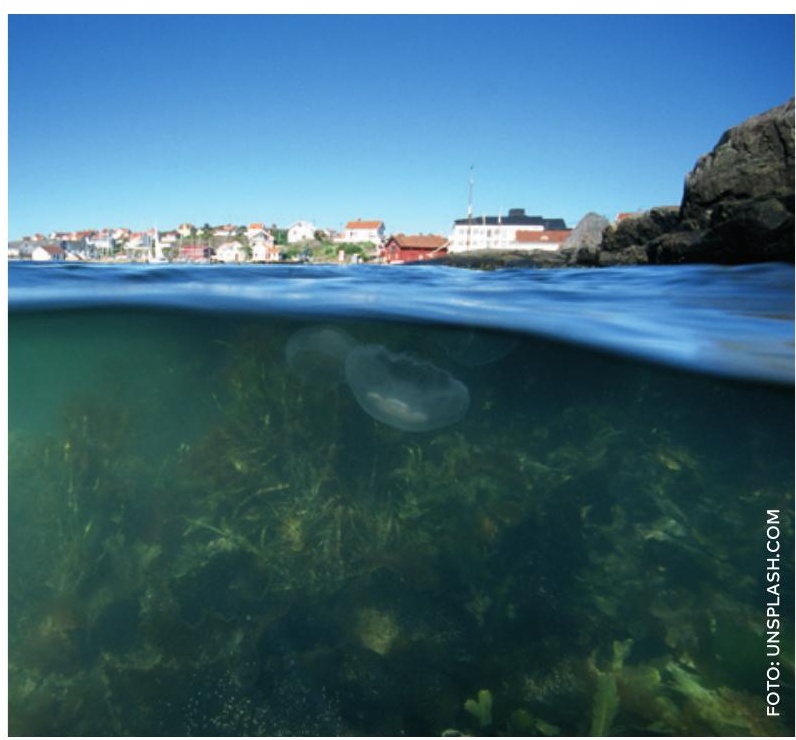




\section{VÅTMARKER}

Våtmarker har stora värden för biologisk mångfald och ekosystemtjänster. De kan både lagra och avge växthusgaser beroende på olika faktorer och vilken typ av våtmark det handlar om. l ett naturligt tillstånd är de värdefulla komponenter i den globala växthusbalansen. Ett känt problem är att dikade våtmarker blir allvarliga koldioxidkällor, en femtedel av Sveriges växthusgasutsläpp kommer från sådana marker.

För att minska de negativa effekterna och bidra till att nå internationella och nationella mål för hållbart användande, biologisk mångfald och klimat är det nödvändigt att förstärka insatserna för skydd, bevarande, skötsel och restau-

\section{.}

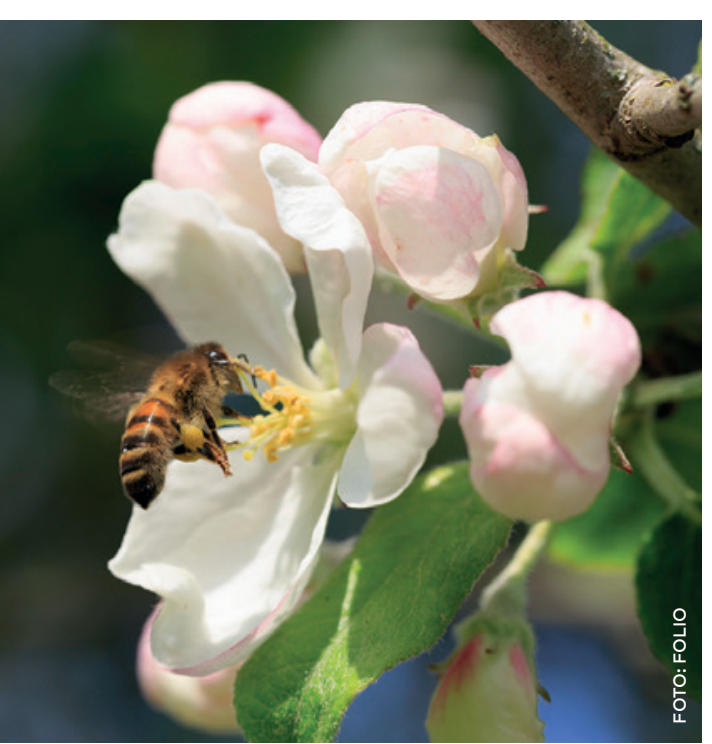

rering av våtmarker. Det finns likheter både avseende utvecklingen för våtmarkerna och skadorna som orsakats miljön och samhället i de nordiska länderna.

\section{Aktivitet}

- Ett projekt för att förbättra kunskapsläget om våtmarkernas status genom att identifiera och kvantifiera nödvändiga insatser för inventering, skydd, bevarande, skötsel och restaurering, samt om möjligt initiera nödvändiga insatser. Projektet kan helt eller delvis fungera som ett nordiskt delprojekt till det treåriga våtmarksprojekt som Sverige initierat i Arktiska rådet och bör även samordnas med det våtmarksarbete som sker inom Barentsregionen.

\section{Ansvarig: Den nordiska Terrestra ekosystemgruppen (TEG).}

Tidpunkt: 2018

Målgrupp: Myndigheter och företag med flera. 


\section{KEMIKALIER}

Den avsatta tiden för att nå det globala målet för kemikalier inom ramen för FN:s hållbarhetsmål och den internationella kemikaliestrategin SAICM är satt till 2020. Detta mål kommer inte att nås och en global process har inletts för att ta fram ett nytt ramverk som ska gälla efter 2020. Sverige vill säkerställa att det kommande ramverket blir ambitiöst. Insikten om att farliga kemikalier och avfall utgör en betydande risk för hälsa och miljö ökar, och blir en allt viktigare fråga för Norden.

Det nordiska samarbetet bör stödja det pågående arbetet med en kommande främjandeplattform för kemikalier och avfall bortom 2020. På så sätt främjas också genomförandet av Agenda 2030 avseende de mål som är relevanta för kemikalier och avfall. Under 2016 och 2017 har det inom ramen för det nordiska samarbetet tagits fram ett förslag om hur ett nytt ramverk kan se ut efter 2020: Chemicals and Waste Governance Beyond 2020. Exploring Pathways for a Coherent Global Regime. Rapporten har fått mycket positiv återkoppling globalt och utgör ett viktigt grunddokument i arbetet med det nya ramverket bortom 2020. Norden bör följa upp och fortsätta vara en drivande kraft i förnyelsen av den globala kemikalie- och avfallsagendan.

\section{Aktivitet}

- Under 2018 arrangeras en konferens/ workshop med förhandlare för att diskutera utformningen av det kommande ramverket med utgångspunkt i det tidigare nordiska arbetet. De nordiska ländernas erfarenhet och arbete med kemikalier och avfallsfrågor lyfts fram. Konferensen kommer att fokusera på att främja diskussionen för initierade förhandlare från EU och andra nyckelländer under den intersessionella processen.

Ansvarig: Miljö- och energidepartementet tillsammans med Nordiska kemikaliegruppen (NKG).

Tidpunkt: 19 januari 2018 Målgrupp: Norden, EU-länder med flera (exempelvis Schweiz, Kanada, Brasilien), EU-kommissionen, NGOs och industrin.

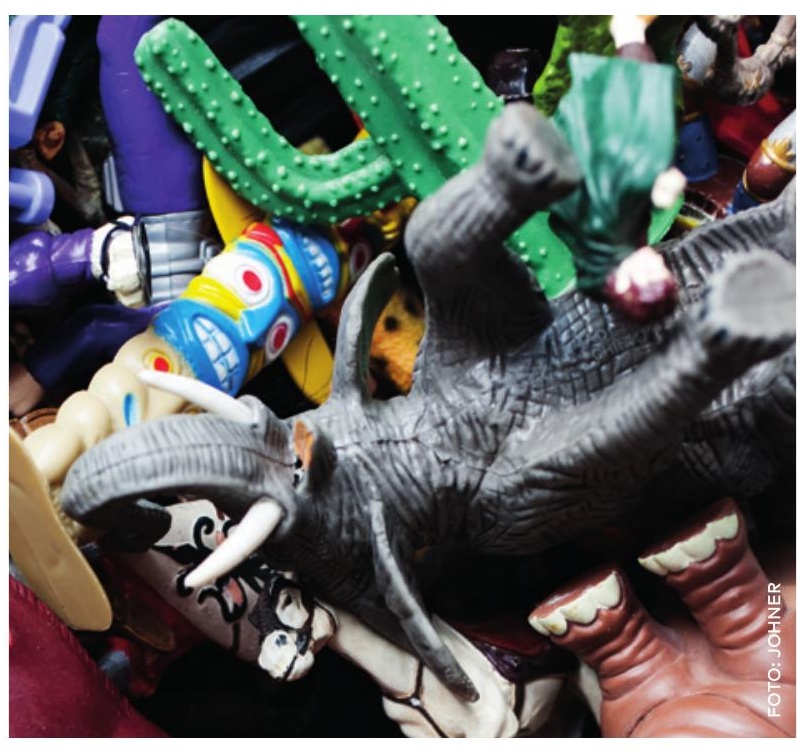




\section{GRÄNSÖVERSKRIDANDE ILLEGALA AVFALLSTRANSPORTER}

De nordiska länderna har ett väl etablerat samarbete inom ramen för verksamheten i Gränsöverskridande avfallstransporter (GRÖT) som är en undergrupp till den nordiska avfallsgruppen (NAG). Arbetet omfattar handläggningen av ärenden, tolkning av förordning, arbete mot illegala avfallstransporter med mera. Varje år genomförs ett projekt och ett årligt GRÖT-möte, men vi ser behov av att ge frågan större uppmärksamhet för att visa att fler åtgärder bör tas mot illegala gränsöverskridande transpor- ter av avfall. Den svenska regeringen beslutade 2015 att skärpa insatserna på området och vill nu lyfta frågan även i det nordiska samarbetet.

\section{Aktivitet}

- En informationsinsats om illegala avfallstransporter genomförs under året tillsammans med berörda aktörer (GRÖT, polisen, tullen, lokala myndigheter).

Ansvarig: Nordiska avfallsgruppen (NAG).

Tidpunkt: Hösten 2018

Målgrupp: Berörda aktörer. 


\section{CIRKULÄR EKONOMI/HÅLLBAR PRODUKTION OCH KONSUMTION}

De nordiska länderna bör även fortsatt samarbeta för att gemensamt genomföra det globala tioåriga ramverket av program för hållbar konsumtion och produktion som ingår som ett mål i Agenda 2030. Arbetet för hållbar konsumtion och produktion går också hand i hand med arbetet att ställa om från en linjär till en cirkulär ekonomi, vilket är en aktuell fråga i alla de nordiska länderna och inom EU. EU-kommissionen presenterade 2015 en handlingsplan för cirkulär ekonomi. De nordiska länderna har uppmärksammat vissa områden som särskilt viktiga och där länderna kan bidra till såväl den nordiska implementeringen, som till arbetet inom EU och globalt. De nordiska samarbetsministrarna har lyft det globala hållbarhetsmålet om hållbar konsumtion och produktion (SDG 12) som ett fokusområde där mål 12.7, som behandlar en grön offentlig upphandling, ingår som delområde.

\section{Aktiviteter}

- Ett seminarium arrangeras, i samverkan med Östersjöstaternas råd, kring grön omställning och grön offentlig upphandling. Sverige är ordförande i Östersjöstaternas råd till sommaren 2018. Rapporter om grön tillväxt och grön upphandling som har tagits fram inom det nordiska samarbetet kan läggas till grund för seminariet. Mötet syftar till att etablera ett nätverk mellan de myndigheter och tjänstemän i regeringskanslierna som har ansvar för grön offentlig upphandling. Mötet kommer att arrangeras på sekretariatet för Östersjöstaternas råd i Stockholm.

Ansvarig: Miljö- och energidepartementet, Östersjöstaternas råds sekretariat, samt Nordregio tillsammans med den nordiska Arbetsgruppen för hållbar konsumtion och produktion (HKP).

Tidpunkt: 19 april 2018

Målgrupp: Representanter för nordiska myndigheter och regeringskanslier i enlighet med ovan. Målgrupp: Berörda aktörer (se ovan).

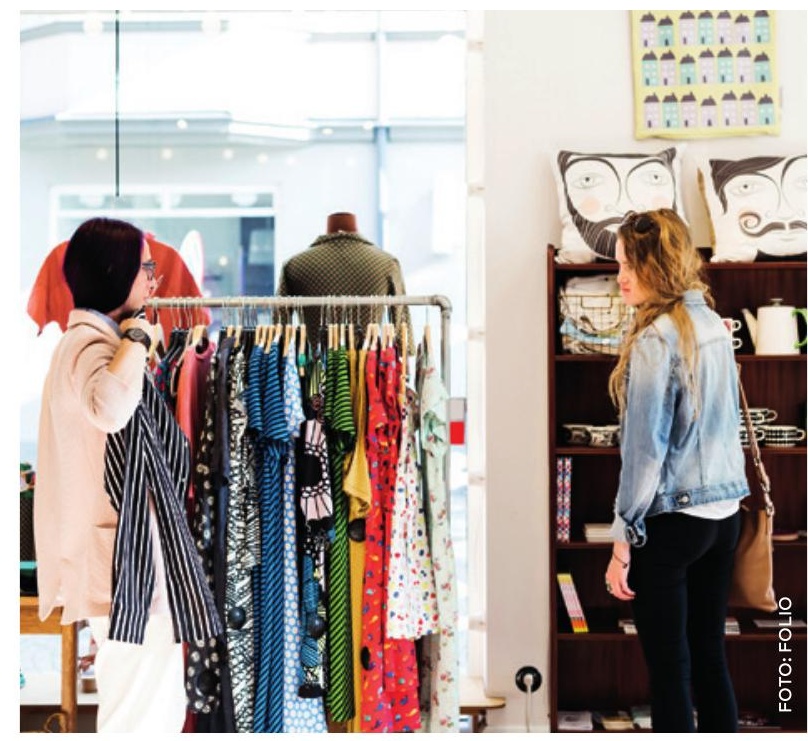


Nordiska ministerrådet

Nordens Hus

Ved Stranden 18

DK-1061 Köpenhamn K

www.norden.org

ANP 2017:793

ISBN 978-92-893-5310-6 (PRINT)

ISBN 978-92-893-5311-3 (PDF)

ISBN 978-92-893-5312-0 (EPUB) 